\title{
VÁLASZTÁSOK ÉS POLITIKAI SZEREPLÖK A DÉL-AFRIKAI KÖZTÁRSASÁGBAN
}

TETLÁK ÖRS

\section{A Dél-afrikai Köztársaság 25 évvel az első szabad választás után és a hatodik szabad választás elött}

Afrika és a világ két történelmi jelentőségü esemény huszonötödik évfordulójára emlékezik idén. A ruandai népirtás szörnyüségei mellett ugyanúgy huszonöt év telt el az első szabad dél-afrikai választás eufóriája óta és ezt a huszonöt évet az Afrikai Nemzeti Kongresszus (African National Congress, ANC) töltötte kormányon. Ez a tanulmány két kérdésre keres választ:

- Képes lesz-e Cyril Ramaphosa elnök kivezetni az államot utóbbi 25 évének legnagyobb válságából, tudja-e konszolidálni a hatalmat gyakorló Afrikai Nemzeti Kongresszust?

- Mik jelenleg a legégetőbb társadalmi-gazdasági kérdések, lesz-e/lehet-e megoldásuk az elnök beiktatását követően?

Az apartheid rezsim békés legyőzése óta sok víz lefolyt az Oranje folyón, ám az ország minden hibája ellenére, alapvetően demokratikus állam maradt. Bár itt is prezidenciális köztársaság az államforma, a kontinens sok más országtól eltérően az erős jogosítványokkal rendelkező államelnök személye rendszeresen és demokratikus választásokat követően változik. Mindez nem jelenti azt, hogy az egyes elnökök teljesítménye, hatalomgyakorlási módszere akárcsak köszönőviszonyban lenne egymással. Az ország éppen egy kilenc éves hanyatlás után próbál magához térni, amit Jacob Zuma elnöksége okozott. A velejéig korrupt ANC-veterán rendszere az állam foglyul ejtésének tankönyvi példáját valósította meg és teljes az egyetértés abban, hogy ez a majdnem két teljes elnöki ciklus az ország elvesztegetett évtizede volt.

Zuma kérdőjelekkel teli regnálásának saját pártja vetett véget, amikor 2018 elején megvonták tőle a bizalmat és lemondásra kényszerítették. Utóda, Cyril Ramaphosa sem kívülről érkezett, szakszervezeti vezetői múltjának köszönhetően az ANC fötárgyalója volt már az apartheid-rezsimmel történő tárgyalásokon is. Niel Barnard ${ }^{1}$ és Roelf Meyer ${ }^{2}$ mellett neki volt a legnagyobb szerepe abban, hogy 1994-re véget ért a békés átmenet és valóban demokratikus választásokat tarthattak. Ramaphosát Nelson Mandela lehetséges utódjaként emlegették, ám miután elvesztette az ANCelnökségért folyó versenyt Thabo Mbekivel szemben, 1997-ben visszavonult a politika első vonalától és az ország egyik legsikeresebb üzletembere lett. 2012-ben 
aztán az ANC alelnökének választották (Zuma körének hathatós támogatásával), majd 2014-ben az állam alelnöki tisztségét is megszerezte. 2017-ben ismét versenybe szállt az ANC elnökségéért és ekkor, ha szủken is, de legyőzte Jacob Zuma volt feleségét és protezsáltját, Nkosazana Dlamini-Zumát, majd Jacob Zuma lemondásával a köztársaság ötödik elnöke lett. Hivatala megkezdésekor a közélet megtisztítását ígérte, új alkotmánybírókat és legfőbb ügyészt nevezett ki, legfontosabb ígéretei pedig a gazdaság felélesztése és a bizalom visszaszerzése voltak. Ramaphosa megújulást, növekedést és az egyre inkább elmaradó befektetések ösztönzését ígérte Dél-Afrika polgárainak. De milyen országot is „örökölt” Zumától?

\section{A választásokat meghatározó legfontosabb társadalmi és közéleti kérdések}

A kontinens egykori „bezzegállama” Zuma elnöksége alatt gazdasági és morális mélypontra jutott. A Dél-afrikai Köztársaság nemhogy a kettösségek országa maradt a meglevő szegregációval, de a társadalmi egyenlötlenségek tovább növekedtek 1994 óta (The World Bank, 2018). A világ valamennyi országát beleértve itt a legnagyobbak a társadalmi különbségek. Nemcsak a nagyvárosok és a vidék között vannak elképesztő és látványos aránytalanságok, de az egyes tartományok között is. Gauteng (a Johannesburg és Pretoria körüli agglomeráció), NyugatFokföld (Fokváros központtal), vagy kisebb részben Szabad Állam tartomány mintha nem ugyanabban az országban lennének, mint Kelet-Fokföld, Limpopo vagy Zuluföld. A területi egyenlötlenségek részben kétségtelenül az apartheid öröksége, hiszen az ország legszegényebb körzetei és községei (municipality) szinte kivétel nélkül egykori bantusztánok ${ }^{3}$ területén vannak. A legszembetünőbb különbségek a nagyvárosok tehetős külvárosai, illetve a gyakran közvetlenül mellettük vegetáló townshipek ${ }^{4}$ (szegénynegyedek) között vannak. Johannesburg peremén az új üzleti negyed, Sandton, vagy az egyik legdrágább lakónegyed, Bedfordview közvetlen közelében vannak olyan sokszor alapvető szolgáltatásokat is nélkülöző többszázezres townshipek, ahol a fekete lakosság tömegei élnek bádogkunyhókban. A legismertebb ilyen település Soweto, mely a maga 1.300.000-res lakosságával a legnagyobb lélekszámú dél-afrikai towhship. Sowetót a lakosságszámot tekintve Tembisa (460.000 lakos, Midrand és Kempton Park területén); Umlazi (405.000, Durban); Soshanguve (400.000, Pretoria); Khayelitsa (400.000, Fokváros); Mamelodi (340.000, Pretoria) és Mitchell's Plain (310.000, Fokváros) követik, de tulajdonképpen valamennyi dél-afrikai város szélén megtalálhatók ezek a szegénynegyedek. Szintén a johannesburgi agglomeráció részét képezik az egymással összeérő Katlehong (410.000 lakos), Vosloorus (160.000), és Thokoza (105.000), ám mivel ezek három különböző településhez (név szerint Germiston, Boksburg, Alberton) tartoznak, a statisztikákban kisebb lélekszámú negyedekként jelennek meg ${ }^{5}$.

Ma a Dél-afrikai Köztársaságban a legoptimistább felmérések szerint is 30\%-os a munkanélküliség (Stats SA, 2019), a realitás azonban ennél jóval magasabb százalék lehet. Az egészen biztos, hogy a fiatal dél-afrikaiak körében eléri a 40\%-ot, ami a szociális feszültségeken és az elképesztő mértékü bünözésen kívül az idegengyülölet erősödésének is kedvez. Ma a lakosság fele a szegénységi küszöb alatt él, ami a 
helyi számítás alapján 992 dél-afrikai rand, azaz nagyjából 20.000 forint /fö /hónap. A lakosság további 25-30\%-a fenyegetett, hogy élete során a szegénységi küszöb alá kerül, míg a serpenyő másik oldalán megközelítőleg $20 \%$-os középosztály és $4 \%$-nyi elit szerepel (World Bank, 2018). A jövedelemelosztásban a fehér kisebbség bỏven felülreprezentált:

- a középosztály $20 \%$-a, az elit $57 \%$-a fehér,

- a krónikusan szegények 95\%-a, a veszélyeztetettek 91\%-a fekete, míg

- utóbbi két kategóriában fehérek elenyésző számban szerepelnek.

Ezek az adatok szolgálnak alapul olyan szélsőséges narratíváknak, amelyeket mindenek előtt a szélsőbalos Gazdasági Szabadságharcosok (Economic Freedom Fighters, EFF) párt hangoztat, de választások idején az ANC egyes körei sem idegenkednek tőle, bár hozzá kell tenni, hogy Zuma és közvetlen köre háttérbe szorulásával az ANC rasszista megnyilvánulásai jelentősen visszaszorultak. Ami változatlan maradt, az a társadalmi mobilitás és a lehetőségekhez való hozzáférés rendkívül alacsony foka, ami föleg más felső és közép jövedelmủ országokkal összehasonlítva mutat sötét képet. Bár a jelenleg is érvényben lévő Nemzeti Fejlesztési Terv (National Planning Comission, 2012) 2010hez képest 2030-ra meg akarja felezni a munkanélküliséget, sőt fel akarja számolni a szegénységet, az ANC kormányok az utóbbi huszonöt évben vízió- és stratégiaalkotásban lényegesen erősebbek voltak, mint végrehajtásban.

A kettősségek másik oldaláról szólva, ma valóban minden a befektetés-ösztönzésről és a munkahelyteremtésről szól. A világon talán itt a leggyorsabb a befektetések megtérülése és a kormány tárt karokkal várja a külföldi tőkét. Ma, nem utolsó sorban a hivatásturizmusnak köszönhetően, Fokváros Afrika leglátogatottabb városa, ám ugyanakkor a világ legveszélyesebb települései között is folyamatosan szerepel (Johannesburggal együtt). Példa a kontrasztra a néhány éve üzembe helyezett MeerKAT ürteleszkóp rendszer, amelynek a közvetlen közelében van számos olyan állami iskola a 4000-ből, ahol a gyermekek számára nem biztosított a higiénikus és biztonságos mellékhelység.

A legszembetünőbb különbségek a nagyvárosok tehetős külvárosai, illetve a gyakran közvetlenül mellettük vegetáló townshipek (szegénynegyedek) között vannak. Johannesburg peremén az új üzleti negyed, Sandton, vagy az egyik legdrágább lakónegyed, Bedfordview közvetlen közelében vannak olyan sokszor alapvető szolgáltatásokat is nélkülöző többszázezres townshipel, ahol a fekete lakosság tömegei élnek bádogkunyhókban. 
A Dél-afrikai Köztársaság egyik legégetőbb problémája a vizhiány és a vízszükösség. 2018-ban Fokváros és a Karoo félsivatag fogyott ki az ivóvízből, 2016-ban pedig a Johannesburgot ellátó Vaaldam víztározóban volt kritikusan alacsony a vízszint. A legnagyobb folyók vízhozama is alacsony ${ }^{6}$, a gát- és víztározó rendszer egyre kevésbé tudja biztonsággal kiszolgálni a folyamatosan növekvő népességet. A felszíni vizek szintje 2015 tavasza (a déli féltekén ősze) óta „alacsony”, idén tavasszal a víztározószintek 11 vízgyüjtő területből 9-en ,átlag alattiak” voltak, illetve a folyók több mint felének vízállása ,alacsony”, több mint negyedének „nagyon alacsony” volt (Donnenfeld, 2019). Mivel az az ENSZ Éghajlat-változási Kormányközi Testülete egyre gyakoribb és súlyosabb aszályokra számít Afrika déli területein is, a Dél-afrikai Köztársaságnak komoly beruházásokra és szemléletváltásra lesz szüksége. A Lesotho-ban folyó víztározó-beruházások kritikusak lesznek a lakosság ellátása szempontjából, ám gyorsabb megoldást jelenthetne a hatékonyabb szennyvíz-kezelés (ma csak 60\%-os), illetve mindenek előtt a vezetékrendszeren keletkező 36\%-os veszteség csökkentése. Ezek az infrastruktúra-fejlesztések a munkanélküliség kérdésére is részben megoldást tudnának kínálni, azzal viszont aligha kezdenének bármit, hogy jelen pillanatban az ország energiafelhasználásának 70\%-át adó szén és a fosszilis technológiák kiváltása megújulókkal csak nehézkesen halad. Nem kedvez az sem, hogy az export jelentős része ásványkincs, és az ország a világ harmadik legnagyobb szén-exportöre. Szorosan összefügg a klímaválsággal, valamint az egészséges vízhez való hozzáféréssel, hogy a Dél-afrikai Köztársaságot is érinti a trópusi betegségekkel fertőzött területek és/vagy a fertőzési időszakok növekedése. A kontinensen ez különösen a zsúfolt, tisztálkodási lehetőségekkel és szennyvíz-elvezetéssel rosszul ellátott lakóterületeken jelent komoly veszélyforrást, márpedig a menekülttáborok mellett, a dél-afrikai bádogvárosok jellemzően ilyenek.

Ahogy részben már említettük, a társadalmi egyenlőtlenségek és feszültségek az idegengyülölet erősödését okozzák. Hiába befogadó ország és hiába volt Mandela politikájának egyik sarokköve az afrikai „testvérek” befogadása, mára a helyzet ennél lényegesen bonyolultabbá vált. Mivel a Dél-afrikai Köztársaságba érkező bevándorlók döntő többsége afrikai származású, az idegengyűlölet sajátos válfajaként egyes szerzők afrofóbiát emlegetnek. 2008 májusa különösen súlyos támadások időszaka volt. Alexandra townshipben, Durbanben, Fokvárosban és Limpopo tartomány városaiban támadtak dél-afrikaiak bevándorlókra. Az attrocitásoknak 56 halottja volt, több százan sérültek meg és több száz felgyújtott, kirabolt üzlet maradt a zavargások után. 2015 is egy különlegesen erőszakos év volt, de szinte nem múlik el hónap, hogy az ország valamely pontján ne támadnának az egyébként nagy számban ott élő bevándorlókra. Ma a dél-afrikaiak 40\%-a megtiltaná külföldieknek vállalkozás indítását, vagy hozzáférésüket a szociális juttatásokhoz, 20\%-uk pedig egyszerủen kitoloncolna minden külföldit, jogi helyzetétől függetlenül (Fabricius, 2019). A számottevő pártok közül az ANC és a legnagyobb ellenzéki párt, a Demokratikus Szövetség (Democratic Alliance, DA) is szigorítaná a fellépést az illegális bevándorlók ellen, míg az EFF határok nélküli országot emleget, ami nem feltétlenül találkozik a dél-afrikaiak többségének elképzeléseivel. A kormányzati kommuni- 
káció sokszor csinál bűnbakot a bevándorlókból saját hibái palástolására, a xenofób támadásokat pedig legtöbbször „egyszerü” támadásokként említi. Ugyanakkor a szigorodó vízumpolitika és a támadások már most is kimutatható károkat okoztak a dél-afrikai gazdaságnak, hiszen egyre inkább elmaradnak a képzett bevándorlók és az állam hitelességének sem tesz jót a bevándorlás nehezítése. Látványos ugyanakkor a képzett (legtöbbször fehér) népesség elvándorlása. Az Egyesült Királyság, Ausztrália, Új-Zéland, Kanada és az Egyesült Államok meglehetősen aktív toborzást folytatnak a Dél-afrikai Köztársaságban, a fehér népességet legalábbis elbizonytalanító jelenségek hatására pedig rendkívüli az a „skill drain” és „brain drain", amivel az országnak szembe kellene néznie. Az elvándorló képzett munkaerö helyére nagyszámú, de képzetlen afrikai bevándorló érkezik, akik mára már teljes városrészekben vannak többségben ${ }^{7}$ és jellemzően a fejlettebb tartományokban, Gautengben és Nyugat-Fokföldön telepednek le nagy számban.

A köztársaságba irányuló bevándorlás intenzitását nagyban meghatározza a déli afrikai régió országainak, elsősorban Zimbabwének stabilitása, gazdasági teljesítménye és aktuális helyzete. A Dél-afrikai Köztársaság természetesen stabil és prosperáló szomszédokban érdekelt, ám jelen pillanatban is dilemma előtt áll. Komolyabb összegü támogatással, pénzügyi beavatkozással kiemelheti Zimbabwét az országot sújtó pénzügyi krízisből, ez azonban várhatóan belpolitikai feszültséget okozna. Vagy az ilyen esetekben kötelező szimpátianyilatkozatok mentén magára hagyhatja szomszédját és ezzel asszisztál Emmerson Mnangagwa elnök „,válságkezeléséhez" - ami adott esetben akár újabb bevándorló hullámot is eredményezhet. Ennél egyértelmübb a helyzet olyan természeti katasztrófák esetén, mint az Idai és Kenneth ciklonok, melyek Mozambikot, Malawit és Zimbabwét tépázták meg 2019 tavaszán. Az ilyen időjárási és klímakatasztrófák százezres nagyságrendben indíthatnak útnak nincsteleneket a térségben, ezekre a mozgásokra pedig az érintett országok mellett a Dél-afrikai Köztársaságnak kell elsősorban felkészülnie.

A Dél-afrikai Köztársaság társadalmi-gazdasági problémáit kivétel nélkül az apartheid örökségeként vezetik le. Ezek közül az eddig elmaradt földreform az, amiben a szegény tömegek talán a leginkább bíznak. Ugyan a kormányzati narratíva szerint állami (önkormányzati és tartományi) földeket érintene a földosztás, illetve például bányavállalatok már nem használt területeit, a közbeszéd kevés kivételtől eltekintve mégis a kompenzáció nélküli kisajátításról szól. Elsősorban a fehér farmerek és általában a fehér kisebbség körében okoz komoly aggodalmakat a reformtervezet, hiszen a cél a fekete közösségek földhöz juttatása lenne. A technikai részletek kidolgozatlansága, az EFF uszítása és az elégtelen kormányzati kommunikáció mellett a legnagyobb riadalmat Zimbabwe példája jelenti, ahonnan a Robert Mugabe nevével fémjelzett rezsim egyszerủen elüldözte a fehér telepeseket. Hiába jelentette ki az ANC 106. kongresszusa, hogy a földreformra kizárólag alkotmányos keretek között kerülhet sor, ez nem feltétlenül nyugtatta meg a kedélyeket. Nem utolsó sorban azért, mert bár Ramaphosa a téma kapcsán kerüli a populista szólamokat, ő maga is megerősítette (igaz, hogy rendkívül gyakorlatias megközelítésben), valamint az ANC választási kiáltványában is szerepelt, hogy meg kell teremteni az alkotmá- 
nyos kereteket a kisajátítás elindításához. $\mathrm{Az}$ alkotmánymódosítás előkészítésére idén februárban parlamenti bizottságot is létrehoztak. Egy ilyen kisajátítás viszont nemcsak a mezőgazdaságnak okozna óriási károkat, de az élelmiszerbiztonságot, az ingatlanpiacot, a jelzáloghitelezést, sőt a munkahelyteremtést is komolyan veszélyeztetné. További probléma, hogy a földhöz juttatni kívánt népesség esetén többnyire a földműveléshez szükséges tudás is hiányzik, míg a farmercsaládok legalább százötven éve ugyanazokon a területeken gazdálkodnak. A „nagy pártok” közül az ANC kiáll a kompenzáció nélküli kisajátítás mellett (bár hangsúlyozza, hogy ez csak egy eleme az átfogó és alkotmányos keretek között megvalósítandó földreformnak) ${ }^{8}$, az EFF ugyanakkor politikájának egyik központi témájává tette, míg a DA határozottan ellenzi azt. Az mindenképpen riasztó, hogy kisebb csoportok már foglaltak le önkényesen földterületeket, éppen a kompenzáció nélküli kisajátításra hivatkozva. Ha ehhez hozzávesszük a távoli farmokon gazdálkodókat ért rendszeres és brutális rablótámadásokat ${ }^{9}$, beláthatjuk, hogy a fehér farmerek nincsenek irigylésre méltó helyzetben.

A közszolgáltatások terén is krízis figyelhetö meg a Dél-afrikai Köztársaságban, hiszen a rossz kormányzás, az állami tulajdonban lévő cégek rossz menedzselése, a minden szinten romboló korrupció és nem utolsó sorban az egyes települések fizetési hajlandósága komoly válságba taszították a legnagyobb állami cégek jelentős részét. Az Eskom (az állami áramszolgáltató) kálváriája a vállalat fizetésképtelenségét és további finanszírozhatóságának végét jelentheti. A helyzet annyira súlyos, hogy a tervezett áramszünetek jelenleg a dél-afrikai mindennapok részei. Hasonlóan nehéz helyzetben van a Transnet (az állami vasútvonal-, kikötö- és csővezeték infrastruktúra fenntartója) és több más állami nagyvállalat. A közszolgáltatások (alapszolgáltatások) kampánytémaként is megjelentek, hiszen a népesség 85\%-a fér hozzá áramszolgáltatáshoz, 92\%-a jobb minőségü ivóvízhez és csak 67\%-a szennyvízelvezetéshez. Már említettük, hogy az energiaellátást 70\%-ban szenes technológiákkal biztosítják és a Nemzeti Klímaváltozási Reagálási Irányelv (National Climate Change Response Policy, 2011) szerint 2025-ig még emelkedni is fognak a kibocsátási adatok, csökkenés pedig csak 2035-től várható. A két legnagyobb károsanyag kibocsátó éppen az Eskom és a Sasol (petrolkémiai konszern), így a megújuló energiára való átállás vagy olyan progresszív intézkedések, mint a szénadó bevezetése igen komoly akadályokba ütköznek. Stagnáló gazdasági adatok 
mellett a kormányzat a legkevésbé sem meri a gazdasági szereplőkre kényszeríteni a nemzeti energiaprogramokban való részvételt, így az ország e tekintetben is olyan külföldi befektetőkre számít, akik hajlandóak finanszírozni az energiatermelési szerkezetváltást. Ugyanakkor kitörö lelkesedéssel fogadta a kormányzat a hírt, hogy a Total konszern jelentős olaj- és gázkészleteket talált a Dél-afrikai Köztársaság partjainál, hiszen a kitermelés megkezdése sok tekintetben változtathat az ország pozícióin. Ramaphosa elnök februári beszédében forradalmi sikernek, az ország jövőjét alapvetően meghatározó eseménynek nevezte a francia vállalat eredményét ${ }^{10}$.

Összefoglalva tehát a választásokra készülő országban a korrupció, az oktatás, a közegészségügy, a munkanélküliség, valamint a lakásügy és az alapvető szolgáltatások jelentek meg kampánytémákként, míg a sajtó várakozásaival ellentétben a földkérdés sokkal kevésbé (Raji, 2019). A kampányt általában neutrálisnak, szinte álmosnak írták le az elemzők, hiszen Zuma háttérbe szorulásával az ANC sokkal visszafogottabb hangnemet engedett meg magának, az ellenzéki pártok pedig semmi váratlant nem húztak elő saját kampányuk során.

\section{A Zondo Bizottság}

A Zondo Bizottság túlzás nélkül a Dél-afrikai Köztársaság jelenének legfontosabb testülete. Hivatalos nevén az Igazságügyi Vizsgálóbizottság az Állam Foglyul Ejtésével Kapcsolatos Ügyekben (Judicial Commission of Inquiry into Allegations of State Capture) 2018 augusztusa óta müködik, Ramaphosa elnök kezdeményezésére. Közkeletű nevét vezetőjéről, Raymond Zondo bíróról, a Legfelsőbb Bíróság elnökhelyetteséről kapta. A bizottság közvetlenül egyáltalán nem avatkozott be a kampányba, ám mivel elsősorban a Zuma korszak visszaéléseivel foglalkozik, ténykedése a közbeszéd részévé vált. Eddigi munkája során olyan esetekben jutott már el a vádemelésig, mint a Gupta-testvérek ${ }^{11}$ korrupciós ügyei és visszaélései, olyan állami vállalatokkal kapcsolatos visszaélések, mint az Eskom (áramszolgáltató), a Transnet (tengeri és vasúti szállítmányozás), a Denel (fegyver- és repülőgépgyártás), vagy a Dél-afrikai Müsorszolgáltató Társaság (South African Broadcasting Corporation, SABC), illetve a bünüldöző szerveket érintő visszaélések. A bizottság meghallgatásai és ténykedése során az ANC vezetőinek legfelsőbb köre, egyben Zuma legközelebbi munkatársai és bizalmasai kerültek látókörbe, akik éveken keresztül fosztották ki az államot, éltek vissza tisztségeikkel és a legelképesztőbb csalásokban és korrupciós ügyekben játszottak kulcsszerepet. Zuma bizalmas emberei közül Bathabile Dlamini, volt szociális fejlesztési és nők helyzetével foglalkozó miniszter ellen például rövidesen vádat is emelnek vesztegetési kísérlet eltitkolása miatt. Zuma kormányának több tagja pedig képviselői mandátumáról is lemondott, ami lehet, hogy csak erőgyüjtés, hiszen Zuma frakciója egyáltalán nem múlt ki, ahogy arról az utolsó fejezetben még szó fog esni.

Mindezek után joggal vetődik fel a kérdés, hogy mit kell még egy pártnak elkövetnie, hogy megrendüljön benne a választói bizalom? Az ANC azonban egészen speciális szervezet. Egyszerre felszabadító mozgalom, párt(szövetség) és igazodási pont. Azzal, hogy a soron következő választás előtt megfelelő időben lemondatták 
Jacob Zuma elnököt, nemcsak időt nyertek, de lehetőséget adtak az ANC és az állam új elnökének, hogy fel tudja készíteni a szervezetet a következő választásra. A legtöbb elemző egyetértett abban, hogy a legrosszabb, ami az országgal történhet, az az ANC szűk többségủ győzelme (McKaiser, 2019), hiszen egy ilyen eredmény a kormánypártot hatalomban tartja ugyan, de Ramaphosa pozícióját jelentősen gyengítené az ANC szervezetén belül. Ami azt is jelentené, hogy a belső csatározások mellett az állam foglyul ejtésében tevőlegesen részt vett egyes csoportok tulajdonképpen zavartalanul folytathatnák üzelmeiket.

\section{A választási eredmények és a választás tanulságai}

A szabad Dél-afrikai Köztársaság hatodik választásán két kamarás parlamentet (Nemzetgyülést és Tartományi Tanácsot) választottak. A szavazók, ahogy eddig is, kizárólag pártlistára adhatták le szavazatuk május 8-án. A 2014-es 29 induló párthoz képest ezúttal 48 állított listát, amit az elemzők a demokrácia ünnepeként értékeltek. Az adatok elemzésekor látni fogjuk, hogy a választók nem osztoztak a lelkesedésükben, hiszen a májusi választás egyik tanulsága éppen a kis pártok háttérbe szorulása volt. 2019-ben került listára a valaha volt legtöbb regisztrált szavazó (ez kizárólag a népesség növekedésének köszönhetö), ám most volt a legalacsonyabb szavazati arány. A regisztráltak 66\%-os részvétele azt jelentette, hogy a szavazáson részt venni jogosult szavazók kevesebb, mint fele adta le szavazatát. Mindenek előtt a 30 év alatti korosztály maradt látványosan távol, legalább fele részük még csak nem is regisztrált a választói jegyzékbe.

Bár voltak ezzel ellentétes félelmek, az idei kampány és a választások nem csak Afrika többi részéhez képest folytak nyugodt mederben, de a korábbi dél-afrikai választásokhoz képest is (Du Plessis, 2019). Ramaphosa nemzetépítésről beszélt és újrakezdést ígért, nem hangzottak el Zuma kedvenc rasszista szlogenjei, kizárólag az EFF „Black First, Land First”'12 kampánya emlékeztetett a korábbi évek populista és fenyegető üzeneteire. A kampány visszafogottságának elsősorban az lehetett az oka, hogy az ANC mintha kerülni szerette volna a számára kevés kivételtől eltekintve kínos témák megjelenését, az ellenzéki pártok pedig nem tudták kihasználni helyzeti előnyüket. A DA figyelmét belső ügyei terelték el, az EFF számára pedig az ANC moderált fellépése nem produkált olyan felütéseket, amire a töle megszokott vehemenciával reagálhatott volna.

2018 végén még könnyen elképzelhetőnek tünt, hogy a szabad köztársaság történetében először koalíciós kormányzásra fog kényszerülni az ANC, erre azonban két okból sem került sor. Mindenekelőtt Ramaphosa személyes sikere, hogy időben az ANC élére állva részben feledtetni tudta a Zuma nevével fémjelzett zsákutcát. A februári SONA (State of the Nation Address, az elnök nyitóbeszéde a parlamenti ciklus elején) legfontosabb üzenetei a fejlődés és a munkahelyteremtés, az oktatás, az életszínvonal emelése, a korrupció, a state capture elleni harc és a gondoskodó állam koncepciója voltak. Márpedig, ahogy az eredmények mutatják, a választók kellő számban hitték el, hogy az új elnök valóban garanciát fog tudni jelenteni a változásra. Másrészt az is igaz, hogy köszönhetően az ország párhuzamos társadal- 
mainak, a szavazók jelentős részéhez el sem jutnak azok az információk, amelyek igazán éles kampánytémákká válhattak volna. Márpedig a Dél-afrikai Köztársaságban is a townshipekben nyernek választást, nem az elővárosokban vagy az egyetemi campusokon.

Minden választási megfigyelő szerint nyugodt légkörben és szervezetten zajlottak a választások az egyes szavazókörökben (összesen 22.000 volt belölük). Az IEC (Independent Electoral Commission, Független Választási Bizottság) és a választásokon dolgozó önkéntesek egyöntetű vélemények szerint kiváló munkát végeztek. Az apróbb hiányosságok egészen biztosan nem befolyásolták a végeredményt, látványos volt viszont a sorukra váró szavazók körében is a fiatalok meglepően alacsony aránya. Kifejezetten progresszív intézkedés volt ugyanakkor, hogy az IEC jó elöre felvette a kapcsolatot és együttműködési megállapodásokat kötött a közösségi média jelentős szereplőivel a választásokkal kapcsolatos beavatkozások (dezinformáció, gyülöletbeszéd és fake news) elkerülése érdekében.

\section{A választásokon résztvevő jelentősebb pártok bemutatása és eredményük elemzése} ANC (African National Congress)

A szociáldemokrata, baloldali-centrista és afrikai nacionalista kormányzó párt számára egyetlen kérdés volt: egy újabb erős felhatalmazás lendületet ad-e Zuma után az újjáépítésre, vagy végleg kiderül, hogy az ANC is része a problémának? Válasz

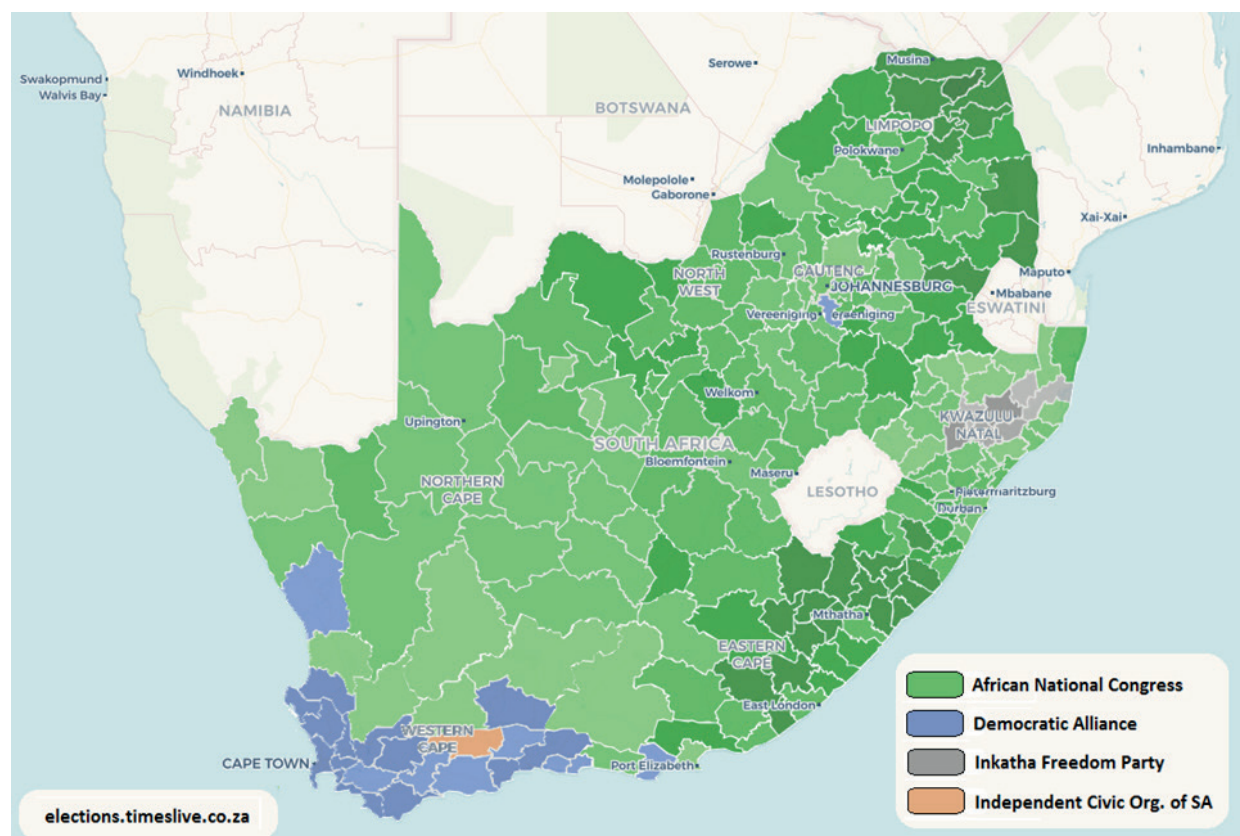

A választások önkormányzat (municipality) szintü eredményei Dél-Afrika térképén

Forrás: https://elections.timeslive.co.za 


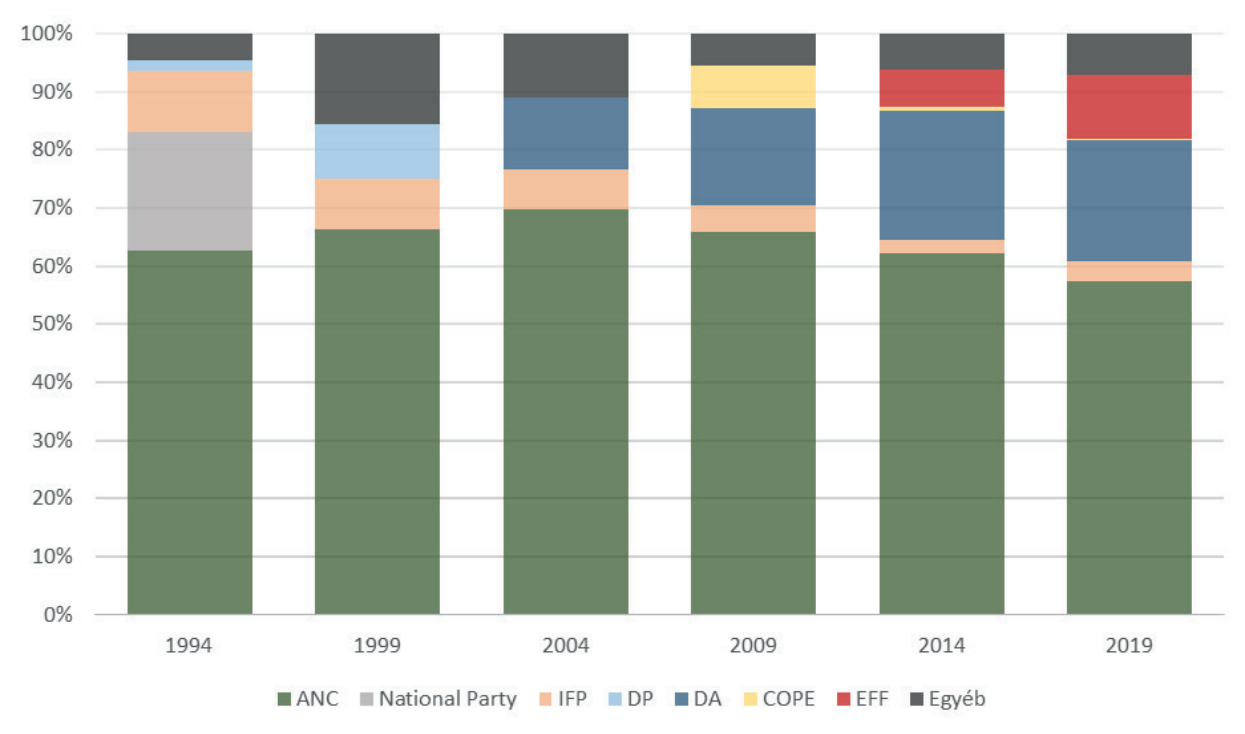

Választási eredmények Dél-Afrikában 1994 és 2019 között az országos választásokon Az adatok forrása: https://www.elections.org.za

csak részben érkezett, hiszen az ANC ugyan a valaha volt legrosszabb eredményét érte el, de még így is kényelmes többségben maradt a kétkamarás parlamentben. Az 5\%-os visszaesés 2014-hez képest dél-afrikai léptékkel komoly kudarcnak is tekinthetö, hiszen az ANC elvesztett 1.400 .000 szavazót. A választók ugyanakkor üzentek is a politikai pártoknak, hiszen nemcsak a részvételi hajlandóság volt kimagaslóan alacsony, de szokatlanul magas volt az érvénytelen szavazatok száma is. Több mint 230.000 érvénytelen szavazat egészen biztosan nem lehet a véletlen műve. Elsősorban a fiatalok maradtak távol a szavazástól, aminek okai között a tartósan magas munkanélküliség, az alacsony fizetések és a kiugróan magas bünözési ráta keresendők. Az ANC is legkevésbé a fiatalokat tudta megszólítani, de komoly visszaesést szenvedett el a townshipekben leadott szavazatok számában is. Mivel a szavazók kizárólag a számukra szimpatikus listára szavazhatnak, személyekre nem (ez egyébként komoly kritikája a választási rendszernek és a rendszer reformjának igénye rendszeresen felmerül), egyáltalán nem lényegtelen, hogy kik vezetik ezeket a listákat. Az ANC esetén Cyril Ramaphosa elnök, David Mabuza alelnök, Gwede Mantashe, az ANC elnöke (chairperson) és a kommunista párt volt elnöke álltak a lista élén, de előkelő helyen szerepeltek a legismertebb kormánytagok is, köztük Nkosazana Dlamini-Zuma „örökös” miniszter, Zuma (egyik) volt felesége. Az ANC 57,5\%-os eredménnyel megnyerte a 2019-es választásokat is, de 2014-hez képest 4,65\%-kal kapott kevesebb szavazatot és 19 mandátumot vesztett a 400 fös Nemzetgyülésben, valamint hatot a 90 fös Tartományi Nemzeti Tanácsban. 


\section{DA (Democratic Alliance)}

A legnagyobb ellenzéki pártot, a liberális, centrista DA-t a 2016-os helyhatósági sikerét követően belső harcok tépázták meg. Mivel a májusi választáson története során először ért el a korábbinál rosszabb eredményt, a pártszakadás sem elképzelhetetlen. Hiába teljesítettek alapvetően jól helyi politikusai 2016 óta, a belső feszültségek elvették az erőt a választásra való felkészüléstől. A párt listavezetője, Mmusi Maimane eddig is a parlamenti ellenzék vezetöje volt, öt viszont viszonylag ismeretlen nevek követték a választási listán. Willem Frederik Faber észak-fokföldi képviselö, Evelyn Wilson, vagy Joe McGluwa ugyan parlamenti képviselőkként készültek az újrázásra, markáns arcoknak viszont aligha nevezhetőek. A DA emblematikus figurái közül Helen Zille nem is volt a listán, Patricia de Lille pedig már korábban kilépett és az általa alapított GOOD párt listavezetőjeként szerzett mandátumot.

Ahogy az az előjelekből várható volt, a DA „elvesztette” Gauteng tartományt, kilenc önkormányzatból (municipality) csak egyet tudott ismét megnyerni. Midvaal/ Meyerton körzetben végeztek első helyen, ott is csak a szavazatok 41.75\%-ával. Az ANC viszont hét körzetben egyedül is többséget tudott szerezni, két esetben $60 \%$ feletti eredménnyel. A gautengi eredmények mutatnak rá azonban arra az örömteli tényre is, hogy a jó kormányzás mégis csak számít a Dél-afrikai Köztársaságban, hiszen az utóbbi időszak tartományi (ANC-s) vezetése nagyságrendekkel jobb munkát végzett, mint elődei, amit a szavazók vissza is jeleztek és a 2016-os helyhatósági vereség után ez ismét az ANC győzelmét eredményezte a leggazdagabb tartományban. A választási eredmények szavazókörzet szintű elemzése még mindig tökéletesen visszatükrözi a gautengi lakosság jövedelmi viszonyait. A tehetős külvárosok és a fehérek által lakott körzetek a DA, a szegény körzetek és a szegénynegyedek (townshipek) pedig az ANC győzelmét hozták. A Johannesburghoz tartozó Soweto és Alexandra, az Ekurhuleni településhez tartozó Tembisa, az agglomeráció déli részén található Thokoza-Katlehong-Vosloorus townshipek, a Pretoriához tartozó Mamelodi mind-mind meggyőző, nem egyszer 80\% feletti ANC győzelmet hoztak.

Nyugat-Fokföld sok szempontból jelentett kivételt ezen a választáson is. A DA hagyományosan itt a legerősebb, idén viszont eredménye visszaesett a korábbi választásokhoz képest. 2014-ben 1.260.000 szavazatot szereztek, ami 59.38\% szavazati arányt biztosított, idén ez 1.140 .000 szavazatra és 55.45\%-os eredményre esett vissza. Hasonlón szerepelt az ANC is a tartományban, a 2014-es 698.000 szavazatból 589.000, a 32.89\%-os eredményből 28.63\% maradt. Új szereplőként a DA-ből kivált GOOD megközelítette az itt hagyományosan gyenge EFF-et (83.000, illetve 62.000 szavazat; 4.04\% illetve 3.01\%), ami a 32.000 Szabadság Front Plusz (Freedom Front Plus, $\mathrm{FF}+$ ) szavazóval meg is magyarázza a DA tartományi visszaesését. Nem szabad elfelejteni, hogy az EFF így is 40.000-rel több szavazatot szerzet 2014-hez képest a tartományban, amivel tulajdonképpen megduplázta korább eredményét.

A DA a 2014-es eredményéhez képest másfél százalékkal kapott kevesebb szavazatot, a Nemzetgyülésben 5 mandátummal szerzett kevesebbet, a Tartományi Nemzeti Tanácsban viszont változatlanul 20 helyet birtokol. 


\section{EFF (Economic Freedom Fighters)}

A szélsőbaloldali populista, fehérellenes EFF akár győztesnek is tekinthetné magát, de céljával ellentétben, egyetlen tartományban sem sikerült olyan befolyásra szert tennie, hogy koalícióra kényszerítse az ANC-t. Összességében szinte megduplázta 2014-es eredményét és minden tartományban jobban teljesített a korábbiaknál. Sorrendben North West 17\%, Gauteng, 13.5\%, Limpopo 13.1\%, Mpumalanga $11.5 \%$, Szabad Állam 11.6\%, Zuluföld 9.9\%, Észak-Fokföld 9.7\%, Kelet-Fokföld 7.7\%, Nyugat-Fokföld $4.2 \%$ eredményeket ért el, amivel harmadik lett a választáson. Választási listáját az a Julius Malema vezette, aki az ANC ifjúsági tagozatának vezetöjeként vált ki és alapított radikális, egyelöre csak külsőségeiben paramilitáris mozgalmat. A pártvezető hivatalos megszólítása föparancsnok a szervezetben, és az aktivisták, sőt a parlamenti képviselők is vörös egyenruhában feszítenek, ami emblémájukká is vált. Malema populista szólamai elsősorban a vidéki és szegény lakosságot érik el, bár a pártvezetés urizálása és korrupciós botrányai köszönőviszonyban sincsenek a párt által hangoztatott üzenetekkel. A májusi listán Malemát Floyd Shivambu alelnök, az ANC ifjúsági szervezetének volt szóvivője, Daluxolo Mpofu pártelnök (chairperson), aki 33 év ANC tagság után lépett át az EFF-be, valamint Hlengiwe Mkhaliphi parlamenti képviselö (a pártszervezetben népbiztos, comissar) követték. Az EFF négy és fél százalékot javított 2014-es eredményén, a Nemzetgyülésben tizenkilenccel, a Tartományi Nemzeti Tanácsban néggyel több mandátumot szerzett.

\section{IFP (Inkatha Freedom Party)}

A zulu nacionalista párt végérvényesen visszaszorult Zuluföldre, kizárólag tartományi szinten jelentős, viszont a májusi választás nyilvánvalóvá tette, hogy a korábban kivált NFP (National Freedom Party) szavazóinak jelentős részét vissza tudta szerezni. A párt listáját a dél-afrikai közélet emblematikus alakja, Mangosuthu Buthelezi pártalapító és törzsi vezető (herceg), volt belügyminiszter vezette. A visszavonulni készülö ${ }^{13}$ és már 91 éves politikust Narend Singh és Liezl Linda van der Merwe parlamenti képviselők, valamint Mkhuleko Hlengwa parlamenti képviselö, egyben az ifjúsági szárny elnöke követték. A kampány során az Inkatha egyik funkcionáriusa ellen történt halálos fegyveres támadás a saját házánál. Szerencsére a helyzet nem eszkalálódott, de a támadás újra előtérbe helyezte a fegyver-beszolgáltatás kérdését. Igazán senki nem tudja, mennyi illegális fegyver van a Dél-afrikai Köztársaság területén, de a fegyveres támadások és a fegyverhasználattal járó büncselekmények számából óriási számokra lehet következtetni. A beszolgáltatás keretei között nyomozás nélkül lehetne leadni illegális fegyvereket, a tervezet végrehajtására azonban mindezidáig nem került sor.

Zuluföldön az Inkatha 14.58\%-kal ért el második helyezést (azaz hivatalos ellenzéki, official opposition pozícióba került), de a DA 14.24\%-kal csaknem utolérte. 1999-ben az IFP még a szavazatok több mint 40\%-ával nyerte a tartományi választást, azóta viszont választásról-választásra szorult vissza, de 2014-hez képest most több, mint 4\%-ot tudott erősödni. Az IFP hét községet tudott megnyerni, 
míg az IFP-ből kivált National Freedom Party 2014-es első indulásakor 6.4\%ot ért el, innen esett vissza 2019-re 1.44\%-ra. A nemzetgyülésbe is mindössze egy képviselőt tud Zuluföldről küldeni az NFP és a számok alapján sejthető, hogy szavazóik jelentős része visszatért az IFP-hez, vagy az ANC-re szavazott. Az ANC 1999 óta mindig tudott Zuluföldön javítani, most viszont 10\%-kal esett vissza (55.47\%), mégis nagyjából minden ötödik ANC-szavazó ebben a tartományban adja le szavazatát. A DA számára Zuluföld volt a három olyan tartományból az egyik, ahol javítani tudott. Észak-Fokföld és Szabad Állam mellett itt is sikerült szerény 1\%-ot javítania 2014-hez képest.

Az IFP egy százalékot javított 2014-hez képest, a Nemzetgyülésben néggyel, a Tartományi Nemzeti Tanácsban eggyel több mandátumot szerzett.

\section{FF+ (Freedom Front Plus)}

Az Afrikaner ${ }^{14}$, konzervatív-populista $\mathrm{FF}+$ lett az 5. legnagyobb párt. Saját léptékkel óriási sikerükre nemhogy az elemzők nem számítottak, de az a párt vezetését is meglepte. North West tartományban 4.05\%-ot, Gautengben 3.86\%-ot, Szabad Államban 3.72\%-ot, Észak-Fokföldön 3.29\%-ot szereztek. Nyilvánvalóan a DA-ben csalódott fehér szavazók pártoltak át nagyszámban hozzájuk, még ha a két szervezet ideológiája a lehető legtávolabb áll is egymástól.

A választási körzetek összetételének érdekességét éppen az FF+ egyik bázisán, Orania ${ }^{15}$ példáján keresztül érdemes bemutatni. A Nyugat-Fokföldön, a Karoo félsivatagban található Thembelihle önkormányzatot (municipality) négy választókörzetre (ward) osztották. Az egyes Strydenburg, ahol az öt szavazókörzetből (voting district) négyben a DA nyert $60 \%$ és $87 \%$ közötti eredményekkel. A legnépesebb szavazókörzet 56\%-os ANC győzelme viszont elég volt ahhoz, hogy az egész választókörzetet az ANC nyerje abszolút többséggel. A hármas és négyes választókörzetek Hopetown városka egyes részei, itt kényelmes ANC többséget hozott a szavazás $(60 \%$, illetve $76 \%$ ). A kettes választókörzet az igazán érdekes, hiszen öt szavazókörzetéből hármat nagy többséggel nyert meg a DA, egyet pedig az FF+ (természetesen ez Orania). A kivétel Hopetown város egyetlen szavazókörzete, amit a város többi részétől eltérően a kettes választókörzethez csatoltak és itt 83\%-os ANC győzelem született. Ez azt eredményezte, hogy hiába tünik úgy a térképen, hogy a kettes választókörzetben DA győzelem született, ha a választókörzetenként összesített eredményekre tekintünk, Hopetown néhány utcányi lakosságának köszönhetően a második választókörzetben is az ANC lett a befutó. Ugyanez így fest a választási térképeken: 
Thembelihle község választási eredménye, zölddel az ANC nyertes körzetei.

Strydenburg (1.) választási körzet eredményei, kékkel a DA, zölddel az ANC nyertes szavazókörzetei.

Hopetown (2.) választási körzet eredményei, kékkel a DA, naranccsal az FF+ nyertes szavazókörzetei.
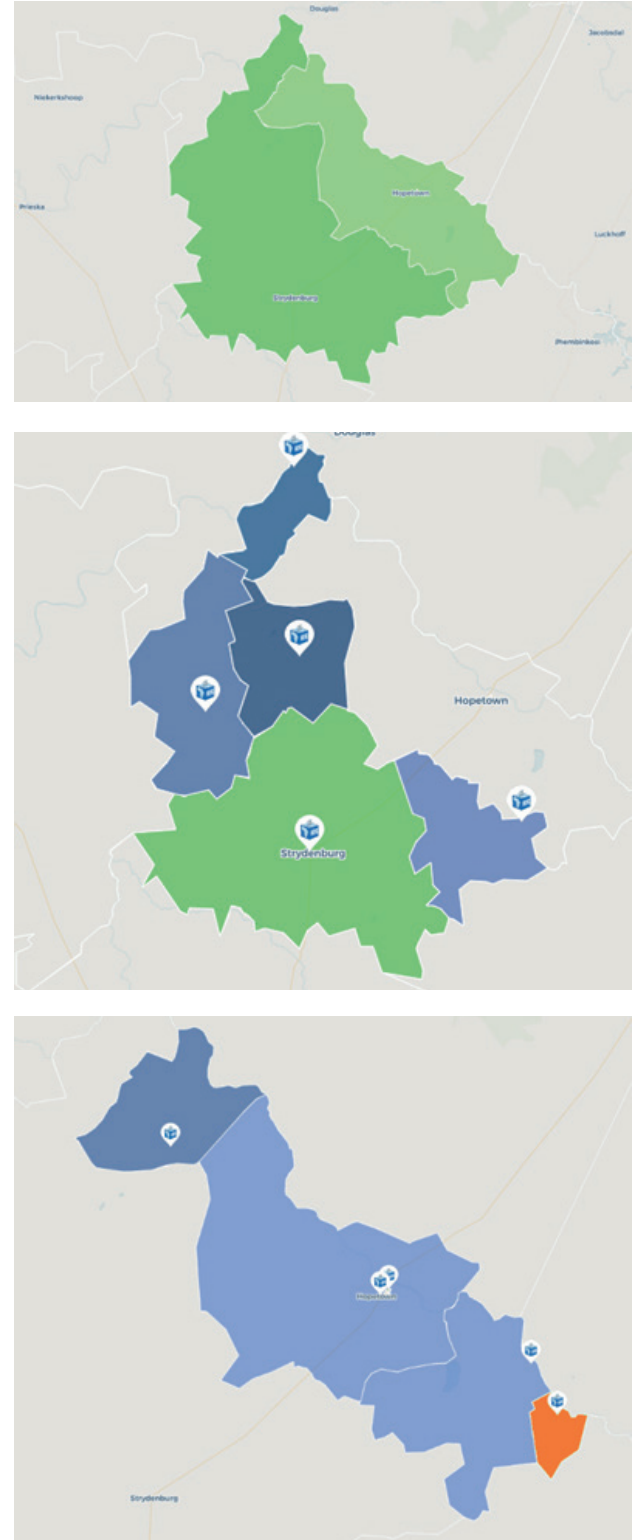

Hopetown második választókörzetének ANC szavazói a városkában zölddel jelölve.

A képek forrása:

https://elections.timeslive.co.za

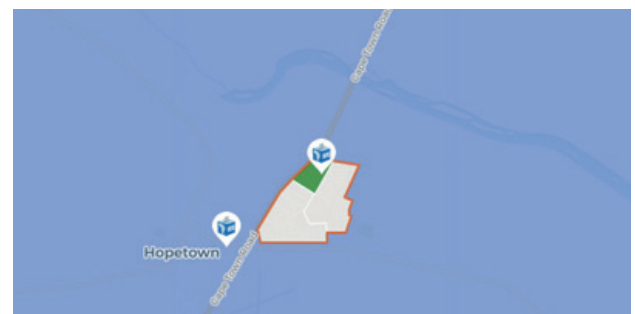


A fentiekből következik, hogy a községszintü választási térképnél lényegesen pontosabb képet mutat a választások szavazókörzet szerinti vizualizációja. A kép forrása az elections.org.za oldal.

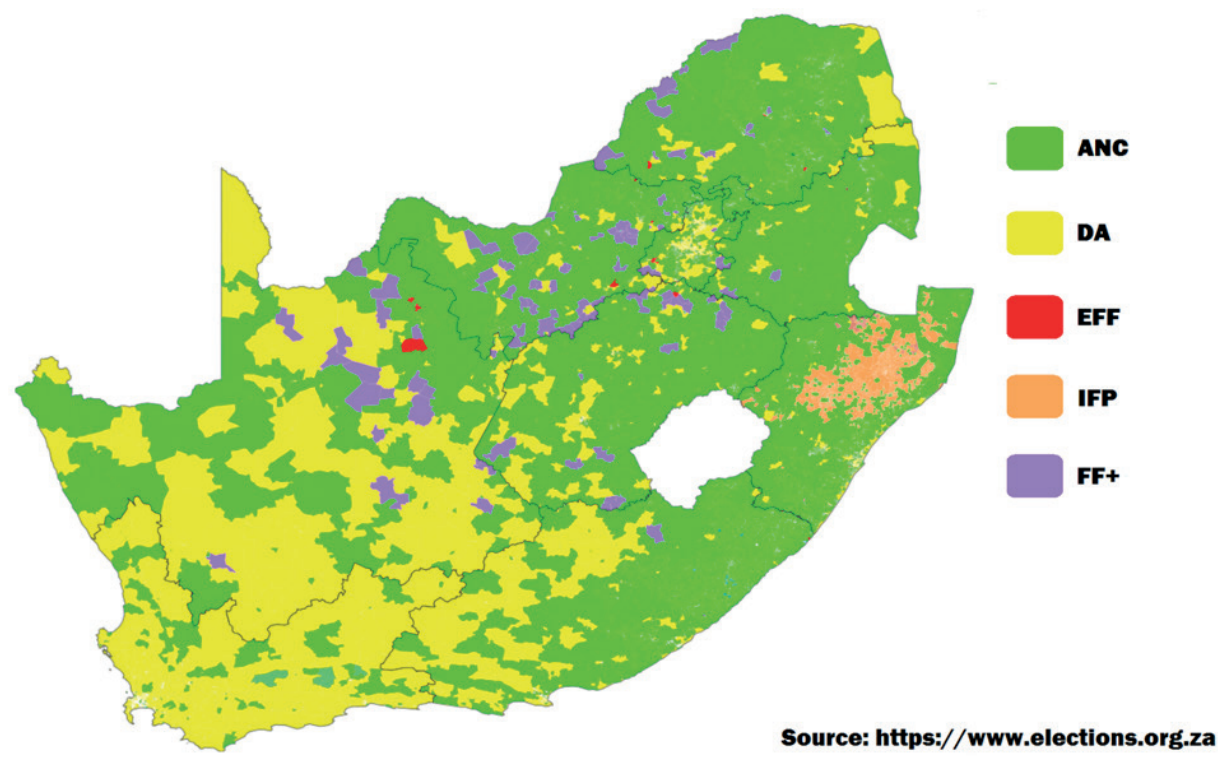

Visszatérve az egyes pártok eredményeire, bár az FF+ és az EFF csak viszonylag kis frakciókat tudnak alakítani, jó szereplésük viszont figyelemre méltó üzenet. Összesen 13\% feletti eredményük kapcsán vannak, akik ünneplik, hogy $87 \%$ centrista pártokra szavazott, de a Dél-afrikai Köztársaság történelmét figyelembe véve a radikális pártokra leadott 13\%-nyi szavazat baljós tendencia.

\section{A választás további tanulságai}

Az ANC és DA elvesztett szavazatai az EFF-nél, illetve az FF+-nál kötöttek ki, illetve előbbi két pártot érintette leginkább a szavazók távolmaradása. Úgy tünik, hogy a DA elszámította magát és a fekete fiatalok felé nyitás okán két szék között esett a padlóra. A fekete fiatalok nem voltak kíváncsiak a DA nyitására, az új narratíva viszont a fehér szavazókat nagy számban tolta az FF+ felé. Az igazsághoz az is hozzátartozik, hogy a DA az utóbbi időszakban a Patricia de Lille-lel való hadakozáson kívüi $1^{16}$ kevés értékelhetö politikai teljesítményt tett lesz asztalra. Voltak olyan várakozások és bevallott céljuk is volt, hogy akár Észak-Fokföldet is megnyerjék, ám ezt messze alulmúlta eredményük, hiszen $25 \%$-os eredményével a DA jelentős vereséget szenvedett itt az ANC-től. A tengerentúli szavazatokat ugyanakkor kényelmes többséggel nyerték meg. 
Az ANC-ből kivált és 2009-ben a semmiből üstökösként befutó COPE (Congress of the People) mára szinte teljesen eltünt. A Zuma és a mindent átszövő korrupció elleni üzenet idén már országosan csak alig 47.000 szavazatra volt elég. Hiába mondhatjuk, hogy az országban tulajdonképpen csak kisebbségek vannak, hiszen meglehetősen heterogén a társadalom, regionális vagy rétegpártként egyedül az IFP tudott komoly eredményt elérni. A korábban Limpopo tartományban kimagaslóan sikeres EFF viszont alaposan meghaladta ezt a kategóriát. Az öt „,nagy” párt mellett további kilenc szerzett parlamenti mandátumot, a GOOD és az ATM (African Transformation Movement) új indulóként 2-2 helyhez jutott a Nemzetgyülésben, illetve kivételes jelleggel tudtak helyi pártok egy-egy szavazókörzetben eredményesek lenni.

\begin{tabular}{l|c|c|c|c|c|c}
\hline & Szavazatarány & $\mathbf{2 0 1 4}$ & Szavazatszám & $\mathbf{2 0 1 4}$ & Mandátum & $\mathbf{2 0 1 4}$ \\
\hline ANC & $57.50 \%$ & $-4.65 \%$ & 10.020 .500 & -1.416 .400 & 230 & -19 \\
\hline DA & $20.77 \%$ & $-1.46 \%$ & 3.620 .700 & -470.900 & 84 & -5 \\
\hline EFF & $10.79 \%$ & $+4.44 \%$ & 1.879 .900 & +710.600 & 44 & +19 \\
\hline IFP & $3.38 \%$ & $+0.98 \%$ & 587.700 & +145.800 & 14 & +4 \\
\hline FF+ & $2.38 \%$ & $+1.48 \%$ & 414.800 & +249.100 & 10 & +6 \\
\hline & & & & & & \\
\hline ACDP & $0.84 \%$ & & 146.300 & +42.300 & 4 & +1 \\
\hline UDM & $0.45 \%$ & & 78.000 & -106.600 & 2 & -2 \\
\hline ATM & $0.44 \%$ & & 76.800 & új & 2 & új \\
\hline GOOD & $0.40 \%$ & & 70.400 & új & 2 & új \\
\hline NFP & $0.35 \%$ & & 61.200 & -227.500 & 2 & -4 \\
\hline AIC & $0.28 \%$ & & 48.100 & -49.500 & 2 & -1 \\
\hline COPE & $0.27 \%$ & & 47.500 & -75.700 & 2 & -1 \\
\hline PAC & $0.19 \%$ & & 32.700 & -5.100 & 1 & - \\
\hline ALJAMA & $0.18 \%$ & & 31.500 & +5.600 & 1 & +1 \\
\hline
\end{tabular}

A választások részletes eredményei és a mandátumszámok a Nemzetgyülésben Az adatok forrása: https://www.elections.org.za

\begin{tabular}{l|l|l|l}
\hline & Legjobb tartomány & Leggyengébb tartomány & \multicolumn{1}{c}{ Községi legjobb eredmény } \\
\hline ANC & $77.0 \%$, Limpopo & $31.2 \%$, Nyugat-Fokföld & $89.9 \%$, Thulamela (Limpopo) \\
\hline DA & $52.4 \%$, Nyugat-Fokföld & $5.4 \%$, Limpopo & $64.7 \%$, Swartland (Nyugat-Fokföld) \\
\hline EFF & $17.1 \%$, North West & $4.2 \%$, Nyugat-Fokföld & $28.2 \%$, Mafikeng (North West) \\
\hline IFP & $14.6 \%$, Zuluföld & $0.03 \%$, Észak-Fokföld & $69.9 \%$, Ulundi (Zuluföld) \\
\hline FF+ & $4.0 \%$, North West & $0.4 \%$, Zuluföld & $13.3 \%$, Kgentlegrivier (North West) \\
\hline
\end{tabular}

$A$,nagy” pártok legjobb és leggyengébb eredményei

Az adatok forrása: https://www.elections.org.za 


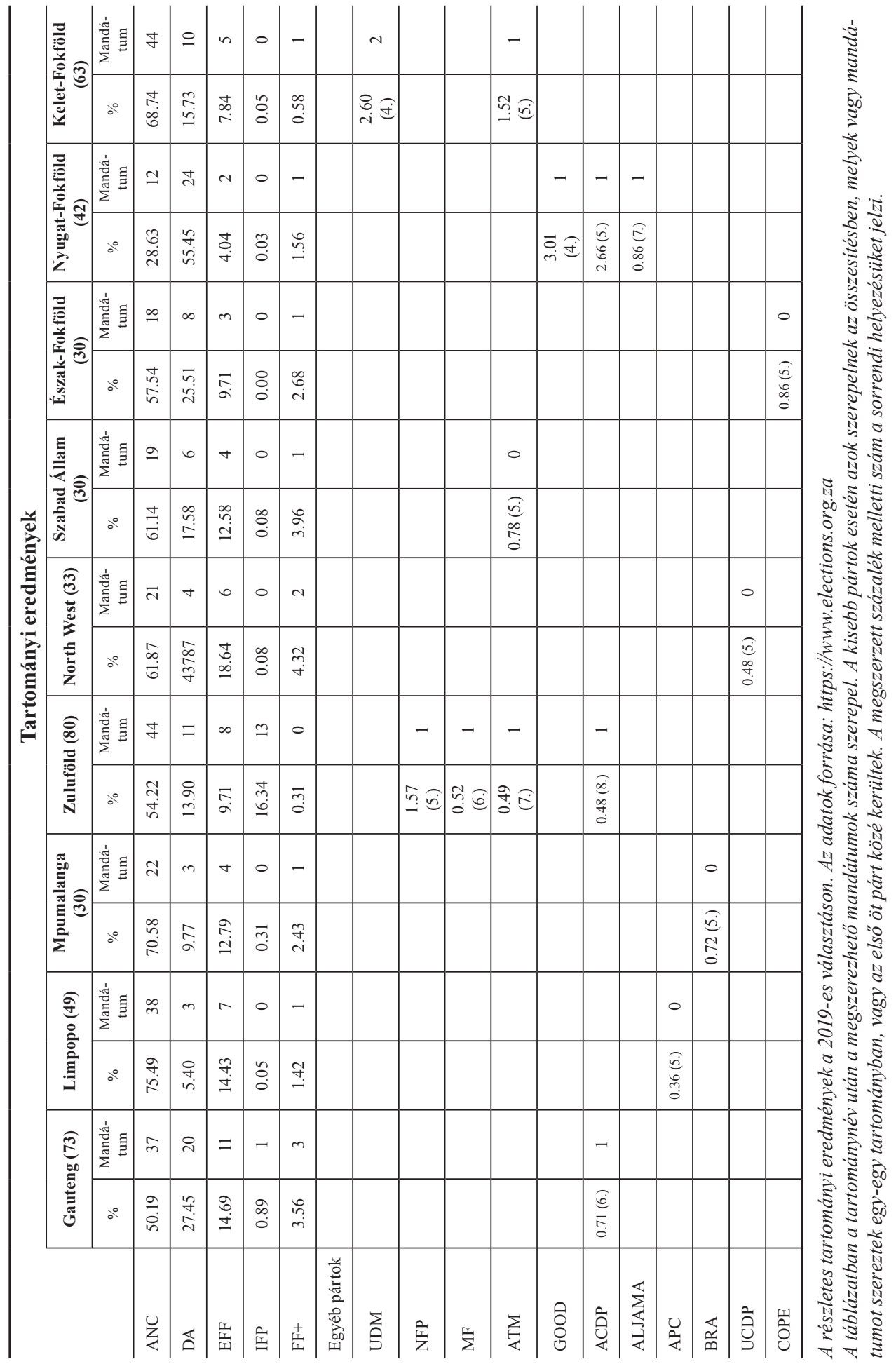


Konklúzióként feltehető a költői kérdés, hogy még minek kellett volna történnie, hogy az ANC eredménye ne érje el az 50 \%-ot? Az hogy az ANC egyáltalán hatalomban maradt, sőt ismét kényelmes többséget szerzett, elsősorban az ellenzéki pártok kritikája, akik nem mutattak kormányképes alternatívát a választóknak. Sem a DA belső feszültségei és szakadása, sem az EFF szélsőséges retorikája és populizmusa nem tudott közel sem elegendő szavazót meggyőzni arról, hogy az ANC helyett valamelyik nagy ellenfelére szavazzanak. A legtöbb szavazót ugyan az ANC és a DA vesztette és a választók távolmaradása is jelentősen rontotta le az ANC eredményét, ez igazán komoly politikai fordulathoz nem volt elegendő.

\section{Az új kormány}

Nelson Mandela példát akart mutatni utódainak, amikor nem is jelöltette magát egy második elnöki ciklusra. Határozott elképzelése volt, hogy Afrika sok más államától eltérően a Dél-afrikai Köztársaságban két ciklusban maximalizálják az elnökség idejét, hogy senki ne tudja a hatalmat ennél a két ciklusnál hosszabban gyakorolni. Törekvése bizonyos szempontból sikert aratott, hiszen Jacob Zuma lemondásával továbbra sincs olyan dél-afrikai elnök, aki kitöltötte volna a második ciklusát. Mandelát követöen Thabo Mbeki éppen az ANC-n belüli hatalmi harcba bukott bele Zuma ellenében, Motlanthe csak az aktuális választásig vállalta az elnökséget (elökészítve Zumának a terepet), majd Zumát is a második ciklusa lejártát megelőzően mondatta le pártja.

Mivel a Dél-afrikai Köztársaságban sem közvetlenül választják az elnököt, az államelnökség a lehetö legszorosabban függ össze az ANC-n belüli hatalmi pozícióval. Motlanthe kivételével ${ }^{17}$ az ország valamennyi elnöke egyben az ANC elnöke is volt. E tekintetben semmiféle változás nincs, hiába mentette meg Ramaphosa szinte egy személyben az ANC-t, a kormányzati és közéleti pozíciók alapvetően még mindig az ANC-n belüli hatalmi dinamika alapján dőlnek el.

Nem lehet eléggé hangsúlyozni, hogy micsoda változásokat hozhat a Zondo Bizottság munkája. Nemcsak az ellenzéki pártok állítják, de a közvélekedés is az, hogy nemcsak az ANC egy-egy frakciója vagy érdekcsoportja korrupt, hanem a teljes szervezet. A szó szoros értelemben nincs olyan ANC prominens (beleértve a regnáló elnököt is), aki ellen ne folyna valamilyen vizsgálat. Angelo Agrizzi, a Bosasa cég korábbi vezetője állította a Zondo Bizottság előtti meghallgatásán, hogy nem csak Zuma elnököt, közvetlen munkatársait és kormányzati tisztségviselőit fizette le a vállalat óriási összegekkel, de Ramaphosa ANC elnöki kampányát is 500.000 dél-afrikai randda $1^{18}$ segítették 2017-ben. Márpedig ezek komoly vádak egy olyan cég vezetőjétől, amely kizárólag állami megrendelésekböl, elsősorban börtönök üzemeltetéséből él és az elmúlt évek során 40 millió(!) randdal támogatta az ANC kampányait. Nem véletlenül nevezte a Zondo Bizottság a Bosasát a legmocskosabb vállalatnak (most tainted company) és nem véletlenül hasonlítja a céget a dél-afrikai sajtó a Gupta-családhoz, amikor az állam foglyul ejtésének haszonélvezőit emlegeti.

Az elnöki beiktatásra szimbolikus napon, május 25-én, Afrika napján került sor. A pretoriai Loftus Versfeld Stadionban teli lelátok elött beszélt Cyril Ramaphosa 
a reményről és a megújulásról, hisz e kettőre különösen szüksége van az országnak a Zumát követő romokon. A beiktatás után néhány nappal (május 29-én) be is jelentette az elnök új kormányának névsorát. A korábbi 36 miniszter helyett csak 28 kinevezésére került sor, bár a minisztériumi struktúrák megváltoztatása következtében az ígért olcsóbb kormányzat aligha fog megvalósulni. A választói akaratnak való megfelelésen túl van néhány olyan szempont, amit egyetlen elnök sem hagyhatott figyelmen kívül kormányalakításkor. Az ANC-n kívül pozíciókat kell juttatni a politikai szövetségeseknek, elsősorban a Dél-afrikai Kommunista Pártnak (South African Communist Party, SACP) és a Dél-afrikai Szakszervezetek Kongresszusának (Congress of South African Trade Unions, COSATU) ${ }^{19}$. Nem hagyhatóak figyelmen kívül az egyes tartományok és vezetőik érdekei, a nemek közti kiegyensúlyozottság a pozíciók betöltésénél ${ }^{20}$ és az ANC ifjúsági szervezeti vezetőinek ambíciói. Még ennél is sokkal fontosabb az ANC frakciói, az egyes erős emberek és érdekcsoportok közti eligazodás. A fentiek következtében Zuma hívei mindenek elött a miniszterhelyettesek között képviseltetik magukat még mindig nyugtalanítóan nagy számban.

Az ország történetében viszont elöször a férfi és női miniszterek létszámát tekintve teljes az egyenlőség. A de Klerk Alapítvány üdvözlő közleményében köszöntötte a hatékonyabb és kisebb létszámú, de nyilvánvalóan nem 100\%-ban Ramaphosa által kiválogatott kormányt, ahol a legfontosabb tisztségeket mégiscsak az elnök bizalmasai töltik be. Kétségtelen, hogy a kulcstárcák jó kezekbe kerültek, de a kormánytagok között vannak igencsak ellentmondásos személyiségek is.

Komoly vitákat vált ki David Mabuza alelnöki tisztsége, akinek regnálása alatt a New York Times szerint (Onishi - Gebrekidan, 2018) az általa irányított tartomány az ország egyik legveszélyesebb régiójává vált. Mabuza Mpumalanga első embereként keveredett korrupciós és hivatali visszaélésről szóló ügyekbe (egy alkalommal a tisztségével összeegyeztethetetlen mennyiségủ készpénzt loptak el a lakásából), de összefüggésbe hozták politikai leszámolásokkal is. Ma ő az ANC három legerősebb emberének egyike, „,királycsinálóként” vett részt a szervezeten belüli pozíció-csatározásokban és nem titok, hogy saját magára mint a köztársaság következő elnökére tekint.

A külügyminiszteri poszton az egyik kormányzati „,veterán”, Dr. Naledi Pandor váltotta Lindiwe Sisulut (a legendás Walter és Albertina Sisulu apartheid-ellenes polgárjogi harcosok lányát), aki cserébe a Település-, Víz- és Csatornázásügyi (Settlement, Water and Sanitation) miniszteri széket kapta meg. Az, hogy egyes miniszterek szinte körforgásban vezetnek más-más minisztériumokat, nem új keletü jelenség az országban. Pandor miniszterasszony vezette már az oktatási, a tudomány és technológiai, illetve a belügyi tárcákat, ahogy Sisulu volt a titkosszolgálati, a lakásügyi, a védelmi és a közigazgatási minisztériumok első embere is, mielött Ramaphosa 2018-ban külügyminiszterré nevezte volna ki. Még náluk is nélkülözhetetlenebb Nkosazana Dlamini-Zuma, aki Afrika-szerte ismert szereplöje a dél-afrikai közéletnek, hiszen az Afrikai Unió Bizottságának elnökeként is szolgált. Ö 1994 óta valamennyi kormánynak tagja volt, jelenleg a Versenyképes Kormányzat 
és Hagyományos Ügyek tárcavezetője ${ }^{21}$. A hölgyeknél maradva, érdekes színfoltja a kormányzatnak Patricia de Lille, a Független Demokraták (Independent Democrats, ID) és a Demokratikus Szövetség (Democratic Alliance, DA) egykori ikonikus vezetője, Fokváros volt polgármestere. A jelenleg a DA-ből kivált GOOD pártvezetőjeként parlamenti mandátumot szerzett politikus kormánytagsága mindenkit meglepett, főleg hogy a kulcsminisztériumnak számító Közmunkák és Infrastruktúra minisztériumot (Public Works and Infrastructure) vezeti. Hogy felkérésével mi lehetett Ramaphosa szándéka, arról egyelőre inkább csak találgatások vannak.

Ayanda Dlondlo most állambiztonsági miniszter lett, de a Zuma kabinetnek is tagja volt (belügyi, közszolgálati és kommunikációs miniszterként) és neki sem makulátlan a múltja. A privát szektorban ténykedve kétes közbeszerzésekben vett részt, egy olyan céget vezetett, amit öt évre el is tiltottak bármilyen kormányzati tenderen való részvételtől. Arról sem sikerült magyarázatot adnia, hogy már kormánytagként miért fizette egy a Guptákhoz és a hírhedt fegyverüzlethez köthető üzletember egy luxusútját Dubaiba. Helyettese nem véletlenül Ramaphosa közeli bizalmasa, aki nyilvánvalóan abban a pillanatban kész lesz a helyére lépni, ha az eddigiekhez hasonló hibát követ el.

Pravin Gordhant, a közvállalatok miniszterét az EFF és az ANC egyes frakciói folyamatosan támadják még az adóhatóság vezetőjeként elkövetett állítólagos botránya miatt és kétségtelen, hogy bár 2014 és 2015 között a Zuma kabinet tagja is volt, ha bünössége bizonyítást nyer, az Ramaphosának fogja a legtöbb fejtörést okozni. A további kulcsfontosságú tárcák közül az a Ronald Ozzy Lamola az igazságügyi miniszter, aki az ANC ifjúsági szervezetének korábbi alelnökeként ${ }^{22}$ nem a legsikeresebben indította karrierjét, hiszen a párt rosszhírének keltése miatt tagságát felfüggesztették, ő pedig néhány évig saját ügyvédi irodájában dolgozott. Most a korrupció elleni harc kulcsfigurájává kellene válnia, bármennyire kevés is a tapasztalata a 35 éves fiatalembernek. A mezőgazdasági, földreform és vidékfejlesztési miniszter, Thokozile „Thoko” Didiza sem nevezhető ellentmondásokat nélkülöző karakternek, hiszen 2016-ban tulajdonképpen az ö jelöltsége miatt történtek halálos áldozatokkal is járó atrocitások Pretoriában (pontosabban Tshwane körzetben). Tito Mboweni pénzügyminiszter sem első posztját tölti be kormánytagként, hiszen már Mandela kormányában is munkaügyi miniszter volt, majd a nemzetközi pénzügyi életben töltött be jelentős tisztségeket. Ebrahim Patel szakszervezeti aktivistaként, majd vezetőként alapozta meg karrierjét. Mielőtt kereskedelmi és ipari miniszter lett volna, tíz évig fejlesztési miniszterként volt kormánytag. Nosiviwe Noluthando Mapisa-Nqakula, aki maga is az ANC veteránja, a 80-as években Angolában és a Szovjetunióban kapott katonai kiképzést, 2012 óta pedig védelmi miniszter. Korábban belügyminiszterként és börtönügyekért felelős miniszterként volt kormánytag, jelenlegi pozíciójára még Zuma nevezte ki és Ramaphosa is változatlan formában tartott igényt szolgálataira. 


\section{Összegzés és záró gondolatok}

Dél-Afrika közéletét ma három erős ember (Cyril Ramaphosa, David Mabuza és Ace Magashule), két erős hivatal (az államügyészség, National Prosecuting Authority és a közvádló, Public Protector), illetve egy még erösebb testület (a Zondo Bizottság) határozzák meg (a hatalmi dinamikáról lásd Haffajee, 2019; Grootes, 2019; du Toit, 2019). Utóbbi mandátuma nem jár le, a meghallgatások egyre szerteágazóbb ügyeket hoznak felszínre, a vádemelések és a vádalkuk pedig egészen biztosan komoly érvágást fognak jelenteni az ANC egyes országos, tartományi, illetve helyi csoportjának. Hosszú idő után fordult most elő, hogy az ANC erős emberei különböző frakciókhoz tartoznak. Ace Magashule (az ANC főtitkára) már a választás előtt is nyilvánosan kritizálta Ramaphosa-t, azt a törekvését pedig nem is különösebben rejti véka alá, hogy a kormányzattól ismét az ANC apparátusa (aminek ő a legitim vezetője) vegye át hatalmi centrumot. Az egészen biztos, hogy a Luthuli Házból ${ }^{23}$ mindent meg fog tenni, hogy Ramaphosa reformjait lassítsa, vagy egyes elemeit akár alá is ássa $^{24}$. Az elnök jó eséllyel támaszkodhat viszont a pártapparátus és a kormányzati vezetők mellett létező harmadik erőközpontra (Eloff, 2019), az alkotmányos intézményekre ${ }^{25}$. Hiszen amennyire erős immár Ramaphosa kormányzati felhatalmazása, annyira gyenge jelenleg a pártapparátusban, ahol Magashule az úr. Elnöki felhatalmazása viszont nem az ANC-től, hanem az alkotmányból ered, melynek intézményei (mindenekelött a bíróságok) kordában tarthatják az ANC bürokratáit. Elemzők is csak találgatnak, hogy Mabuza alelnök hol is áll pontosan az elnök és a fötitkár közti vetélkedésben, de Ramaphosa 57\%-os eredménye abban a tekintetben óvatosságra intheti, hogy ez az eredmény közvetlenül Zuma után bőven elég arra, hogy Ramaphosa kitöltse ötéves mandátumát.

Már érintettem, hogy Ramaphosa Thabo Mbeki elnökhöz hasonló karakter, nemzetközi szintéren elkötelezett és Afrikára fókuszáló elnök, akinek a legfontosabb feladata a befektetői bizalom visszaszerzése és a stagnáló gazdaság új pályára állítása. Reményt és megújulást ígér az országnak, a fejlesztést, a fejlődést tartja legfontosabb törekvésének. A kormány éppen csak elkezdte a munkát, de nyilvánvaló, hogy a tisztviselöi kar cseréje nélkül lehetetlen lesz egy tisztességesebb és jobban müködő államot teremteni. Bár lényeges személycserék már Ramaphosa ideiglenes elnöksége alatt is történtek, az államigazgatás jelentős részét lehetetlen hetek-hónapok alatt lecserélni. Márpedig a lehető legrosszabb gyakorlatok túl mélyen vannak kódolva az állam működésében, az állami vezetők legfelsőbb körétől az utolsó tisztviselőig hatott át mindent és mindenkit a korrupció. Hasonlóan komoly és csak hosszú távon orvosolható probléma, hogy helyi szinteken a vezetők jelentős része egyszerüen alkalmatlan a feladatára. Van például olyan város, ami hiába fekszik csak néhány kilométerre a Vaal folyótól, a vízellátó rendszer hiányosságai miatt folyamatos vízhiánnyal küzd.

Zuma és követöi önként biztosan nem fognak börtönbe vonulni és minden befolyásukat latba fogják vetni, hogy ellehetetlenítsék az ellenük folyó eljárásokat. Eljárási hibák keresésében eddig is kiválóan teljesítettek, sőt igény szerint a törvényhozás lehetőségeit sem vonakodtak kihasználni. Ugyanakkor Ramaphosa 
kormányzati legitimációjával és az alkotmányos intézmények tőlük lényegesen függetlenebb müködésével erre sokkal kevesebb lehetöségük lesz. Mivel ennek az érdekcsoportnak egyes tagjai mind országos, mind tartományi szinten pozícióban tudtak maradni, a teljes erkölcsi megtisztulás biztosan lassú és körülményes folyamat lesz. Éppen az ő hatalomban maradásuk vetette fel ismét a kérdést, hogy miért nem lehet változtatni a választási rendszeren? Hiszen amíg a választó kizárólag egyetlen pártlistára szavazhat, szinte semmi befolyása nincs arra, hogy kiket is juttat be a parlamentbe. Ha személyekre lehetne szavazni a listán (vagy épp ellenkezőleg, kizárni személyeket a szavazattal a listáról), nem kizárólag a pártközpontok döntenének a választói felhatalmazás „felhasználásáról”. Az minden bizonnyal igaz, hogy az ANC listán előkelő helyen szereplő lejáratódott politikusok taszították a választókat, de földcsuszamlásszerü változást még ez sem okozott. Márpedig az ANC belső mechanizmusára egyelöre nincs direkt hatással sem az országos vagy tartományi választás, sem a sajtó vagy a bünüldöző szervek tevékenysége. Amíg pedig megvan a parlamenti többség, ez a belső mechanizmus nem fog változni. A bünüldöző testületek munkáját ezért is kíséri fokozott figyelem, hiszen a közvélemény felelösségre vonást követel. Mivel például a közvádlót csak a parlament hívhatja vissza, itt megint csak abba a kérdésbe ütközünk, hogy éppen melyik ANC-vezető személyére vonatkozóan folyik nyomozás és ennek a vezetőnek milyen támogatottsága van az ANC parlamenti frakciójában.

Álljanak itt végezetül Ramaphosa elnök célkitüzései a következő tíz évre, melyeket június 20 -i parlamenti nyitóbeszédében nevesített. A szegénység, az egyenlötlenségek és a munkanélküliség leküzdésével azt kívánja elérni, hogy tíz éven belül senki se legyen éhes a Dél-afrikai Köztársaságban; a gazdaság fejlődjön lényegesen gyorsabban, mint a népesség; 2millió fiatal szerezzen munkát; teljesítsen sokkal jobban az iskolarendszer és minden 10 éves tudjon olvasni; valamint feleződjön meg a bünözési ráta. Ez utóbbi tekintetében örvendetes, hogy a kormány „klaszterei” közül éppen az igazságügy, bünmegelőzés és biztonság az, ahol az elnöknek leginkább elkötelezett miniszterek dolgoznak. Így van rá esély, hogy a célkitüzéseknek megfelelően egy hatékony, etikus és fejlesztő állam váljon az országból, amely képes meghaladni Zuma rossz kormányzását és visszatalál arra a Mandela által kijelölt útra, ami a Dél-afrikai Köztársaságot a kontinens vezető államává tette.

\section{Jegyzetek}

1 A titkosszolgálatok vezetőjeként a tárgyalásos megegyezés elkötelezett híve volt.

2 De Klerk államminiszter kormányában az alkotmányos ügyek és kommunikáció tárca vezetőjeként volt a Nemzeti Párt főtárgyalója, majd tagja volt a Nemzeti Egységkormánynak is. A Nemzeti Párt megszűnése után alapította meg az Egyesült Demokratikus Mozgalmat (United Democratic Movement, UDM), majd 2000-ben visszavonult a politikától és üzleti tevékenységbe kezdett. 2006-ban belépett az ANC-be és nemzetközi konfliktusok rendezésében közvetítöként, konzultánsként vállal szerepet.

3 Bantusztánok az apartheid-rezsim által létrehozott olyan „törzsi területek” (tribal homeland), ahová a fehér kormányok kényszerítették a fekete népességet. Ezek a területek önkormányzásra, önálló fennmaradásra képtelenek lettek volna, bár a dél-afrikai kormány egyes 
bantusztánokat önálló államként is elismert. A lakosság ezeket a területeket csak külön engedéllyel (általában munkavégzés céljára) hagyhatta el.

4 Általában megkülönböztetik a township és a location/squatter camp fogalmakat. Elöbbieknek egészen városszerü utcái, negyedei is vannak, utóbbiak tulajdonképpen semmiben sem különböznek a brazil favelláktól, vagy más afrikai bádogvárosoktól. A két kategória nem különül élesen egymástól, azonos utcában, sőt ugyanazon a telken is megtalálható mindkét típus.

5 Az adatok az utolsó, 2011-es dél-afrikai népszámlálás kerekített eredményei (BusinessTech, 2016).

6 Összehasonlításképpen a három legnagyobb dél-afrikai folyó. Az Oranje folyó vízhozama a Dráva fele, a Limpopo folyóé nagyjából megegyezik a Muráéval, a Vaal pedig a Szamossal. Dél-Afrika népessége viszont lassan eléri a 60.000 .000 föt.

7 Johannesburg szebb napokat látott belvárosának Hillbrow városrészében például $80 \%$ a külföldi lakosság aránya (Fabricius, 2019).

8 Meg kell ugyanakkor jegyezni, hogy Ramaphosa elnök - ahogy az várható volt - 2019. június 20-i parlamenti nyitóbeszédében, immár a választások után, kerülte a kompenzáció nélküli kisajátítás kifejezést, de hitet tett egy tulajdonjogokat tiszteletben tartó földreform mellett.

9 Az utóbbi évtizedekben ezrével(!) történtek ilyen rablótámadások (farm attacks), Dél-Afrika valamennyi tartománya érintett az esetekben. Jelentős a halálos áldozatok száma és a hírek rendszeresen mutatnak be sokkoló képsorokat ezekről a támadásokról. Egy a támadásokat kivizsgáló tényfeltáró bizottság viszont arra a megállapításra jutott, hogy a támadások indítéka csak kisebb részben rasszista, elsősorban a vagyonszerzés a motiváció. A társadalmi párbeszédet és a megoldást ugyanakkor nem segítette, hogy a rendőrség hosszú éveken keresztül csak esetlegesen hozott adatokat nyilvánosságra és nem feltétlenül tünt együttmüködőnek a támadások megelözése érdekében.

10 A februári State of the Nation Address alkalmával így fogalmazott az elnök: ,a catalytic find....could well be be a game-changer for our country"(Ramaphosa, 2019. február).

11 Az indiai származású, 1993-ban Dél-Afrikába érkezett család Zuma elnöksége tett szert elképesztő gazdasági befolyásra és vagyonra, botrányok és visszaélések sorát produkálva. A Gupták már a kétezres évek elején is feltüntek Zuma támogatói között, amikor még alelnökként versengett Thabo Mbekivel a hatalomért. Családjának több tagját is fontos pozíciókba helyezték cégcsoportjukban, majd Zuma elnöksége alatt szinte árnyékkormányként telepedtek rá az államra, nemcsak az állami megrendelések és koncessziók kegyeltjeiként, hanem direkt ráhatással az állami kinevezésekre is. Ténykedésük már komoly veszélyt jelentett a demokratikus intézményrendszerre, ahogy vagyonuk jelentős részét is jórészt illegális tranzakciókkal menekítették Dubaiba, illetve Indiába. Ma dubai „önkéntes száműzetésben” próbálják minél messzebbről elkerülni a dél-afrikai hatóságokat.

12 Buthelezi az IFP augusztusi kongresszusán már nem indult az elnöki tisztségért. Így az IFPnek 1975-ös alapítása óta először lett új elnöke Velenkosini Hlabisa személyében, aki az ellenzék hivatalos vezetője KwaZulu-Natal tartomány törvényhozásában..

13 Ha igazak a hírek, Buthelezi az IFP következő, augusztusi kongresszusán már nem indul az elnöki tisztségért, így az IFP-nek 1975-ös alapítása óta először lesz új vezetője.

14 Afrikaner szervezetről lévén szó, pártjukat afrikansz anyanyelvükön Vryheidsfront Plus-nak hívják.

15 Az egykori Fokföld és Szabad Állam határán lévő kisvárost 1991-ben kezdték el Afrikanerek (búrok) benépesíteni. A város az afrikansz identitás megörzését tűzte ki célul, ma ezernéhányszáz, kizárólag fehér lakosa van. Forgatócsoportok kedvenc állomása, hiszen a városnak önálló pénzneme, az állami berendezkedéstől független önkormányzata és szinte teljesen önfenntartó közössége van. Orania városát a májusi választáson 80\%-os eredménnyel nyerte meg a Vryheidsfront Plus, az itt második DA pedig 11\%-ot szerzett. 
16 A politikusnő egy kínaiak által elnyert fokvárosi elektromos autóbusz tender okán vált kegyvesztetté a DA-ben.

17 Motlanthe csak átmeneti időszakra vállalta a tisztséget, így elég volt az ANC alelnökségéig, illetve fötitkárságáig jutnia.

181 dél-afrikai rand valamivel többet ér, mint 20 forint.

19 Ez a háromoldalú szövetség 1990-ben jött létre, Forradalmi Szövetségként az apartheid ellenes küzdelem jegyében. A kommunisták és a szakszervezetek sosem indultak önállóan a választásokon, vezetöik azonban kivétel nélkül helyet kapnak a dél-afrikai kormányokban.

20 Ebben a tekintetben Dél-Afrika mindig is a skandináv modelleket tekintette követendőnek.

21 Ez a minisztérium a tartományokat, a helyi önkormányzatokat és a tradicionális vezetőket érintő ügyekkel foglalkozik.

22 Nem mellékes, hogy ugyanekkor volt ugyanennek az ifjúsági szervezetnek az elnöke Julius Malema, az EFF vezére.

23 Ez az ANC központja.

24 A dél-afrikai politika jelentős alakjai tesznek néha egészen elképesztő kijelentéseket, vagy valósítanak meg olyan politikát, ami a szó szoros értelmében ellentmond a józan észnek. Magashule úgy oldaná meg a munkanélküliség és a szegénység kérdését, hogy több pénzt nyomtatna, Zuma amikor nemi erőszakkal vádolták, azt nyilatkozta, hogy azért kizárt, hogy veszélyben lett volna az egészsége (a hölgy HIV-fertőzött volt), mert az aktus után lezuhanyzott. De az egyébként számos erénnyel rendelkező Thabo Mbeki is konzekvensen tagadta a HIV és az AIDS elleni küzdelem létjogosultságát.

25 Az alkotmány 9. fejezete hat a kormányzattól független intézményt hozott létre, melyek feladata az alkotmányos rend és a demokrácia védelme. Ezek az közvádló (public protector); a Dél-afrikai Emberi Jogi Bizottság (South African Human Rights Comission, SAHRC); a kulturális, vallási és nyelvi közösségek védelmére létrehozott bizottság (Comission for the Promotion and Protection of the Rights of Cultural, Religious and Linguistic Communities, CRL Rights Comission); a nemi egyenlőség bizottsága (Comission for Gender Equlity, CGE); az általános pénzügyi ellenőr (auditor general) és a Független Választási Bizottság (Independent Electoral Comission, IEC). Arról eltérőek a nézetek, hogy az Icasa (Independent Communications Authority of South Africa) része-e ennek a fejezetnek, hiszen a szöveg említ egy országos független müsorszóró vállalatot, de nem nevesíti az Icasa-t.

\section{Felhasznált irodalom}

- BusinessTech (2016): These are the biggest townships in South Africa (2016. augusztus 14.) Elérés: https://businesstech.co.za/news/general/132269/these-are-the-biggest-townships-in-south-africa/

- Donnenfeld, Zachary (2019): Water security in South Africa: forgotten but not gone (Institute for Security Studies, 2019 március 22.) Elérés: https://issafrica.org/iss-today/water-securityin-south-africa-forgotten-but-not-gone

- Du Plessis, Carine (2019): We should be grateful for boring elections (Daily Maverick, 2019. május 8.) Elérés: https://www.dailymaverick.co.za/article/2019-05-08-we-should-be-gratefulfor-boring-elections/

- Eloff, Theuns (2019): What to do in the last days before the sixth democratic election? (FW de Klerk Foundation, 2019. május 6.) Elérés: https://www.fwdeklerk.org/index.php/en/latest/ news/888-article-what-to-do-in-the-last-days-before-the-sixth-democratic-election

- Eloff, Theuns (2019): Stumbling blocks and power blocks call for cool heads (FW de Klerk Foundation, 2019. június 14.) Elérés: https://www.fwdeklerk.org/index.php/en/latest/ news/902-article-stumbling-blocks-and-power-blocs-call-for-cool-heads 
- Fabricius, Peter (2019): Xenophobia? What xenophobia, we love foreigners! (Institute for Security Studies, 2019. április 4.) Elérés: https://issafrica.org/iss-today/xenophobia-whatxenophobia-we-love-foreigners

- Grootes, Stephen (2019): The Long and Winning Road: David Mabuza (Daily Maverick, 2019. június 3.) Elérés: https://www.dailymaverick.co.za/article/2019-06-03-the-long-and-windingroad-david-mabuza/

- Haffajee, Ferial (2019): Cyril Ramaphosa loses third power play to Ace Magashule in under two weeks (Daily Maverick, 2019. június 5.) Elérés: https://www.dailymaverick.co.za/ article/2019-06-05-cyril-ramaphosa-loses-third-power-play-to-ace-magashule-in-under-twoweeks/

- Institute for Security Studies: Public protest and violence map. Elérés: https://issafrica.org/ crimehub/maps/public-violence

- Isike, Christopher (2019): Factionalism and corruption could kill the ANC unless it kills both first (The Conversation, 2019. május 12.) Elérés: https://theconversation.com/factionalismand-corruption-could-kill-the-anc-unless-it-kills-both-first-116924

- McKaiser, Eusebius (2019): A Clean President Can't Govern From Atop a Tainted Party (Foreign Policy, 2019. május 7.) Elérés: ttps://foreignpolicy.com/2019/05/07/a-clean-presidentcant-govern-from-atop-a-tainted-party-respected-president-rotten-party-south-africa-cyrilramaphosa-jacob-zuma-anc-ace-magashule/

- National Planning Comission: Our future - make it work (National Development Plan 2030, 2012. augusztus 15.) Elérés: https://www.gov.za/issues/national-development-plan-2030

- Onishi, Norimitsu - Gebrekidan, Selam (2018): South Africa Vows to End Corruption. Are Its New Leaders Part of the Problem? (New York Times, 2018. augusztus 4.) https://www.nytimes.com/2018/08/04/world/africa/south-africa-anc-david-mabuza.html

- Overcoming Poverty and Inequality in South Africa - An Assessment of Drivers, Constraints and Opportunities (The World Bank, 2018 március) Elérés: http://documents.worldbank. org/curated/en/530481521735906534/pdf/124521-REV-OUO-South-Africa-Poverty-andInequality-Assessment-Report-2018-FINAL-WEB.pdf

- Raji, Rafiq (2019): Will loyalty factor decide elections? (NewAfrican, 2019 május, 52-54. oldal, IC Publications)

- Statistics South Africa (Stats SA, 2019): Discouragement decreases and unemployment increases in the second quarter of 2019 (2019. július 31.) Elérés: http://www.statssa.gov. $\mathrm{za} / \mathrm{p}=12376$

- Tepperman, Jonathan (2018): Where There Has Been Wrongdoing, There Will Be Accountability (Foreign Policy, 2018. szeptember 27.) Elérés: https://foreignpolicy. com/2018/09/27/where-there-has-been-malfeasance-and-wrongdoing-there-will-beaccountability-south-africa-cyril-ramaphosa-corruption/

- du Toit, Pieter (2019): Political risk analysis: Major shifts and key players (News24, 2018. június 14.) Elérés: https://www.news24.com/Analysis/political-risk-analysis-major-shiftsand-key-players-20190613

- Cyril Ramaphosa elnök parlamenti nyitóbeszédei - State of the Nation Address, 2019. február és június. Elérés: https://www.gov.za/state-nation-address

\section{A választási eredményekhez felhasznált adatok forrásai:}

- Választási eredmények a Választási Bizottság hivatalos oldalán: https://www.elections.org.za

- A Sunday Times választási oldala: https://elections.timeslive.co.za

- A Statistics South Africa (Stats SA) 2011-es népszámlálásának adatai:

- http://www.statssa.gov.za/?page_id=3955 
A szerzőről

Nemzetközi kapcsolatok

szakértő, a Budapesti Corvinus

Egyetem PhD hallgatója.

Kutatási területe a

regionalizmus a szubszaharai

régióban és Dél-Afrika szerepe

a nemzetközi rendszerben.

\section{About the Author}

International relations

specialist, PhD student at the

Corvinus University of Budapest.

His research topic is

regionalism in sub-Saharan

Africa and the role of South

Africa in the global system.

\section{English Abstract}

\section{Elections and political actors in the Republic of South Africa}

After the wasted decade of the Zuma presidency, Cyril Ramaphosa promised a renewal in South Africa in 2018. The post-state capture condition of the former economic and moral champion of the continent did not favor to regain either the confidence of the voters or of the investors. While the country had been prepairing for the sixth free general elections ( 25 years after the fall of the apartheid-regime), most of the domestic socio-economic problems remained unsolved. Inequality, unemployment, education, corruption, land reform and provision of public services are still the most important topics of the public talk and determined the focus of the campaign. The publication introduces the party structure of the country, the leaders of the biggest South African parties, what is more the causes and the consequences of the sixth consecutive success of the African National Congress (ANC). The article includes an analysis of the results of the national and provincial elections and beside the electoral analysis the author tries to introduce the dynamics of power within the factions of the ruling African National Congress party, adding an outlook on the members of the new Ramaphosa Cabinet. Last but not least the publication describes the most important authorities and bodies who tackle the thriving corruption in the ANC and in the subsystems of the state. 